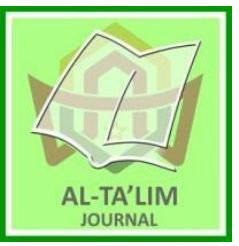

AL-TA'LIM JOURNAL, 28 (3), 2021, (247-260)

(Print ISSN 1410-7546 Online ISSN 2355-7893)

Available online at http://journal.tarbiyahiainib.ac.id/index.php/attalim

\title{
Developing Jurisprudential Inquiry Based Learning Model of Teaching Fiqh at Madrasah Tsanawiyah
}

Received: 26 $6^{\text {th }}$ July 2021; Revised: $23^{\text {th }}$ November 2021; Accepted: $30^{\text {th }}$ November 2021

Permalink/DOI: http://dx.doi.org/10.15548/.

\section{Rahmiati *)}

Institut Agama Islam Negeri Bukittinggi, Indonesia.

E-mail: rahmiati@iainbukittinggi.ac.id

\section{Muhammad Zubir}

Institut Agama Islam Negeri Bukittinggi, Indonesia.

E-mail: mzubir@iainbukittinggi.ac.id

\section{Muhiddinur Kamal}

Institut Agama Islam Negeri Bukittinggi, Indonesia.

E-mail: muhiddinurkamal@gmail.com

\section{Muhamad Rezi}

Institut Agama Islam Negeri Bukittinggi, Indonesia.

E-mail: rezineddin@gmail.com

\section{Muhammad Zainuddin bin Arrifaldi}

University Tekhnologi Malaysia,

Malaysia

E-mail: mzainuddin5@graduate.utm.my

\section{*) Corresponding Author}

Keywords: Learning; inquiry; jurisprudential.

\begin{abstract}
Learning is the most significant activity in education. Through learning activities, the goals of education are achieved. Students' success in learning mostly depends on their mastery to learn independently and on how they manage their study. The research aims to develop learning model at Madrasah Tsanawiyah, to make the learning process triggers students to be more creative and study better. The method used in the research refers to the nature of Research and Development. The steps of the study are preliminary study, development, and product test. The study found that the development of a jurisprudential inquiry-based learning model for learning Fiqh helps students to improve their learning outcomes. The model has significantly proven effective to support students' behavior change, thus their achievement increases.
\end{abstract}

How to Cite: Rahmiati, R., Zubir, M., Kamal, M., Rezi, M., \& Arriafdi, M. (2021). Developing Jurisprudential Inquiry Based Learning Model of Teaching Fiqh at Madrasah Tsanawiyah. Al-Ta lim Journal, 28(3). doi:https://doi.org/10.15548/jt.v28i3.719

\section{INTRODUCTION}

Learning has several elements. They are students, teachers, and curriculum or learning materials (Radianti et al., 2020; Wyatt-Smith \& Klenowski, 2014). Teachers have to master learning strategies that can activate students to involve in varied learning processes (Rido et al., 2015; Schumacher et al., 2013). It implies that teachers should not only explain or talk about the learning materials, yet they are supposed to have different and various learning media (Sigit et al., 2019; Supriyanto, 2018; Tamrin et al., 2017). Therefore, students are interested to study.

Fiqh is one of the subjects offered at Madrasah Tsanawiyah. This subject is in line with one of the goals of national education, 
specifically those related to Syariah Islam and its implementation (Arifin et al., 2019; Budiman et al., 2021; Nisak et al., 2021). There are two main goals of learning fiqh, first, the knowledge that the students have to understand or the learning materials that should be prepared, and second, the use of relevant methods so that fiqh can be better understood by the students (Budiman \& Samani, 2021; Mansir et al., 2020). Referring to a preliminary study which has done at Madrasah Tsanawiyah Koto Tuo, it was found that the goals of learning fiqh were not yet achieved. Students' motivation and interest were low. The learning materials are mostly based on memorizing theories, not yet applying problem-solving methods. Learning facilities were incomplete, learning strategies were ineffective, teachers' teaching techniques were monotonous were some other possible causes of the inability to achieve the expected learning outcome. Therefore, it is necessary to implement learning strategies that motivate students to be actively involved in the learning process. Teachers are expected to shift from the result-oriented paradigm to the process-oriented.

It is important to select and decide which learning sources and which media can facilitate the shifting of the paradigm. Theoretically, one of the innovative approaches is jurisprudential inquiry learning. Its learning strategy is believed effective to help teachers improve the learning process quality. Therefore, it is necessary to conduct a study that observes how this learning strategy suits the demands of learning fiqh. The observation aims at developing a jurisprudential inquiry-based learning model.

The inability to gain the expected learning outcome, referred to as the students' grades, is possibly caused by the learning strategies applied by the teachers is inappropriate (Akbar, 2021). Teachers often ignore the learning principles that can trigger or stimulate students' motivation, interest, and creativity to study and to solve their learning problems (Wijanarko, 2017). The topics are taught within the given time, referring to the syllabus, yet how the topics are presented mostly one-way communication, from the teacher to the students (Hasanah, 2019).

To minimize the problems found during the fiqh learning process, it is important to apply one learning strategies that motivate students to actively involve during the lesson. The teachers shift from result to process-oriented, thus, the teachers should be able to select and design interesting learning strategies. It can be done by selecting the resources, media, and appropriate approach. jurisprudential inquiry learning is believed effective to help teachers promote their learning process.

Referring to the previous explanation, it is important to conduct research that develops a jurisprudential inquiry-based learning strategy. This strategy leads the students to think systematically and critically in terms of responding to issues related to fiqh happening at schools or in society (Horsley, 2010; Nava-Aguirre et al., 2019). This strategy suits the demands of learning figh that require students to think logically and systematically in solving fiqh problems. Students can state their opinions on what they think best to do as a solution to a case. Students are allowed to make decisions by applying the learning strategy, focusing on their thinking ability, that in the end, they come up with the best decision. It is then conducted a study aiming at developing the jurisprudential inquiry-based learning strategy titled The Development of Jurisprudential Inquiry-Based Learning Strategy at Madrasah Tsanawiyah Koto Tuo.

\section{Learning Strategy}

The word 'strategy' is defined as an art of doing; tactics or plans (Taufik, 2012). According to (Neil \& Higham, 2012), strategy is action plans that aim at solving problems or achieving intended goals. (Oxford et al., 2014) says the strategy is a way or method, principles applied to reach the expected target(Ismail, 2008). Strategy can also be defined as plans that contain series of actions designed to get what is wanted. In line with. 
The term 'strategy' is mostly used in the military is defined as ways to utilize all forces to win the war. Strategy is used to consider how the forces are seen from both aspects; powers and weapons. The strategy includes gathering information about the opponent, such as the numbers of its soldiers or its weapons (Priambodo et al., 2020).

Teachers' strategy is a plan that teachers execute to optimize the students' potential so that they are actively engaged in the learning process and gain the expected learning outcome (Nasution, 2018). In education, strategy is defined as plans that contain series of actions designed to achieve the goals of education. Learning strategy is also defined by Kemp, quoted by (Sanjaya, 2010) that says strategy as learning activities are done by the teachers to help students gain the learning outcomes effectively and efficiently. Based on the opinions, Dick and Carey also state that learning strategy is a set of learning materials and procedures used together to promote learning experiences.

Referring to the previous definitions of strategy, it is possible to say that learning strategy is series of actions that cover the use of methods and the use of various learning resources during the learning activities designed to gain the goals of education. It implies that designing strategy covers from drafting up to organizing the work plan, it is not yet doing the action. Strategy is arranged to get certain targets, therefore, decisions to set up the strategy are based on the achievement of goals. The steps in the strategy include utilizing various facilities and learning sources (Hasbullah et al., 2019).

\section{Learning Fiqh}

Fiqh is derived from the Arabic word ("faqiha"). where its qaf word means Fahima or understand like how Arabians say "faqiha anni ma bayantu lahu" which means he understands what I am telling. Fiqh is alfiqhu, which means knowing and understanding something (Thohari, 2013). Despite the debates between the meaning of fiqhu and fahmu, experts believe that fiqhu has fahmu in its definition, that is understanding both concrete and abstract things (Rezi et al., 2018).

The term fiqh means Syariah or Islamic laws that relate to mukallaf, taken from detailed propositions of the syara'. Fiqh is the knowledge obtained from ijtihad. Fiqh explains the laws of Islam or syara' obtained from tafshil propositions talk about issues in amaliyah done by Mukallaf (Busyro, 2018). Fiqh is one of the subjects taught at Islamicbased schools such as Madrasah Tsanawiyah. This subject prepares the students to know, understand, comprehend, and implement the Islamic laws that later will be the students' way of life reflected through guidance activities, teaching, training, and experiencing (Ismail, 2016). As a system of the national curriculum, the curriculum of figh at the Madrasah Tsanawiyah should implement different strategies to promote active learning for its students.

The problems of learning fiqh are possibly caused by various learning factors. The factors are identified from instruments such as curriculum, learning materials, teachers or learning resources, facilities and managements at schools, the raw input such as students' characters both physiology and psychology, teaching-learning processes such and environmental input such as climate, physical environment, social economy, religions, and output (Rahman et al., 2019).

\section{METHOD}

The design of the research is the Research and Development, covering two phases of research. The first phase or Phase I is developing the learning instruments that are used in teaching fiqh, referring to the Jurisprudential Inquiry learning strategy. The second phase or phase II is testing the instruments using pretest-posttest control group design. It is to gather information about how far the students learn by looking at the students' learning outcomes. This design refers to the concept delivered by Seels and Richey (Seels \& Richey, 2012). The product of the research is a set of jurisprudential inquiry learning instrument for teaching fiqh 
The development model is established based on the 4-D development model (define, design, develop and disseminate) (Sugiyono, 2015). The implementation of the jurisprudential inquiry-based learning model is done to make a certain product that is effectively tested: 1) Preliminary Study, 2) Development, 3) Product testing. The subject of the research is students Madrasah Tsanawiyah Koto Tuo Kabupaten Pasaman. The learning process is mostly teachercentered, despite each school has different orientations and characteristics. Fiqh is chosen because its characters and topics are related to problems commonly faced by society.

The Madrasahs are selected since the schools are famous for their combination of learning figh that utilizes the Kitab Kuning. The Madrasah is also awarded by the Ministry of National Education as the Integrity School. The data are collected to limited tests and teachers of fiqh are involved in the design of the learning instruments which is based on the Jurisprudential strategy. The learning framework follows that applied at schools, but the learning steps follow the draft concepts of designing a Jurisprudential strategy-based learning instrument (Setyosari, 2010).

The instrument is developed within two forms:1) the treatment, 2) the measurement. The treatment is given to the experimental group, while the measurement is used to measure the scores from both groups; the experimental group and control group. They are also analyzed quantitatively referring to the characteristic of test analysis (Amalia \& Supranata, 2020). Significant test results in learning fiqh are then followed by implementing limited test using the strategy which applies the experiment method; Single one-shot Case Study.

\section{The Jurisprudential Inquiry Learning Strategy in Learning Fiqh}

To gain the learning outcomes or to solve learning problems faced by students, a certain strategy is needed in any teaching and learning process. In learning fiqh, a learning strategy is needed to help students better understand the lesson. Strategy is a way to get something or to reach the intended outcome. A learning strategy is chosen and designed by referring to the topics of the lesson which emphasize more on the student's activities.

One of the strategies or a real action that can be implemented during the learning process is applying the Jurisprudential Inquiry learning strategy. It is a strategy that stimulates students to think systematically and critically in terms of responding to the issues or problems faced by the students either at school or in society. This strategy suits the demands of learning fiqh that requires students to have logical thinking ability which is systematic to solve problems related to Islamic law. Shortly, implementing this strategy helps students to focus more on the thinking process which is needed in learning fiqh.

Besides, the jurisprudential inquire learning strategy is suitable for Madrasah Tsanawiyah because the schools expect their students to think critically, logic and systematically. The principles of this strategy are; a) abstracting the values of real-life situations. The students have to see concrete situations by referring to the ethical frame applied. b) the use of general concepts. It means the students see possibilities from the concept of values used. c)identifying disagreement in values. In other words, it is to decide values that can be abstracted in a situation. d) examining the values decided. Here, the students examine how effective the assumptions or the decisions made (Priansa, 2017).

\section{Students' Learning Outcome}

Students' learning outcomes are things that students gain after following series of learning activities; class presentations or behavior changes. The learning outcomes can be shown in the form of numbers or letters that converse and describe students' mastery of what has been learned. A learning outcome is one of the indicators to know how successful students learn. According to (Saifulloh \& Darwis, 2020), there are six goals of students' learning outcomes 
evaluation: a) providing information about students' progress as an effort to gain the aims of study through varied learning activities, b) providing information that can be used to plan and manage students' follow up activities. c) providing information that can be used to understand students' competence, to frame their problems and obstacles, to decide suitable solutions. d) giving information that can be used as the backbone to motivate students about their progress in studying and to stimulate them to study better, e) providing information about all aspects of students' behavior that teachers can support their development to be part of society, f) providing appropriate information that can assist students to decide which schools to go, or which professional work to choose that suit their interest and talent. The students' learning outcome can be obtained from tests that are evaluated by teachers.

\section{Data Analysis}

Before designing the development, the research is begun by observing literature that discusses learning strategies and theories applied to improve students' learning outcomes. It is found that students can develop and improve their thinking ability and their learning outcomes if the learning strategy implemented, is engaging. Some other literature findings related to the study are:

Learning strategy is a learning activity that teachers should provide so that students can gain their expected learning outcome effectively and efficiently. Strategy is used as the guidelines in the learning process. The learning outcomes can be students' achievement, students' behavior changes. The learning outcome meant in this study is the students' cognitive aspect that students obtain after completing the test of lesson that developed based on the jurisprudential inquiry learning model.

During the learning process, according to the concept of education, a student is tied to the interest of study, the process of learning, and the learning outcome. If a student is engaged in a study, thus his interest to know more about the study improves. Interest strongly relates to attention that appears when students like the learning process. Students' interests positively motivate them to study and follow the learning process. Students' interest covers the engagement of study, being aware of the advantages of following the lesson, and the frequency of their study. Interests provide significant energy that stimulates students to study and learn. It is possible to state that students' interests influence them to pay attention to, to follow what is being taught, that they learn because they want to.

Referring to the previous description, the learning strategy developed should be varied and interesting for the students. Once the students feel interested and engaged in the process, they will actively involve in the learning process, which leads to the possibility of gaining the intended or expected learning outcomes.

\section{The Needs Analysis}

Once the theories related to developing students' learning interests, the study is then continued to observing and interviewing the teachers and students at Madrasah Tsanawiyah Koto Tuo. Based on the interview results with the teachers at Madrasah Tsanawiyah Koto Tuo, it is found that students prefer to learn equipped with different or various learning methods or strategies provided by teachers. The headmaster of the school and the teachers as well state that varied methods and strategies of learning trigger and attract students' attention to participate actively in the learning process. It is proven when there are studies of observations done at Madrasah Tsanawiyah Koto Tuo applying various learning models, the students are more active to follow the lesson. Based on the interview done with the students at Madrasah Tsanawiyah Koto Tuo, they confirm that they prefer to have a fun learning process that is offered by certain strategies applied by teachers during the class. Students say that they can easily understand and better know what is being discussed or explained compared to the 'old way when 
teachers conduct the class by referring to the conventional way of teaching and learning. By applying certain learning strategies, students are helped to learn better.

\section{Instrument Validation}

Before corresponding the draft of the inquiry learning strategy model in learning fiqh at Madrasah Tsanawiyah Koto Tuo, some experts are involved in validating the instruments. The instruments are revised as how the validators suggest and then are returned to be evaluated. The first revision is done by adding indicators of evaluation and the evaluation of language used.

The draft if-then revised again. Then, it is sent back to the validators. It is then concluded and confirmed in Chapter III, where the instrument is found to be valid since $75 \%$ of the validators confirm its validity.

\section{The Development Validity}

The design of the learning instrument is done by understanding various literature that supports the design of the learning model applying the concepts of jurisprudential inquiry learning strategy. Discussion with the expertise is done before the learning model is implemented. The learning instruments include the lesson plan, learning materials for the fiqh class that applies jurisprudential inquiry learning strategy, it is communicated to teachers of fiqh about how the design is applied. The validity result of the development includes the aspects of; 1)the rationale of the instrument, 2)the evaluation of learning materials presented, 3)the suitability of each learning aspect, 4)the evaluation of language used, and 5)the presentation of the product.

Once the measurement of instrument validity and the suitability of learning instruments, FGD is programmed and training to use the instruments is given to the teachers of a tested group and experimental groups. Revisions are made, and the model is adjusted whenever such details are found unsuitable. The evaluation shows that the characteristics of learning instruments applying the jurisprudential inquiry learning-based strategy are different from other types of learning instruments. The characteristics mainly can be seen in the presentation of the lesson plan. The model makes the students' motivation to learn fiqh improve. They gain a lot of advantages. According to the evaluation of the developed learning instruments, the process of learning fiqh applying the jurisprudential inquiry learning strategy offers a lot of usefulness for the students, specifically in terms of students' motivation. Therefore, the rationale of the learning instruments used for teaching and learning fiqh meets the demands of the study.

Evaluators conclude the problems presented by the learning instrument applying the jurisprudential inquiry learning strategy are contextual. The materials presented are familiar for the students, thus during the learning process, the students eager to know more even the students want to try to find additional theories that relate to the topic being discussed. Theories are discussed to suit the theories of learning for students' development. The materials presented are believed representative and suitable for learning fiqh at Madrasay Tsanawiyah. How the materials are organized is systematic. Each topic is related thus it obtains 'high category' from the evaluators.

Evaluators also state that the learning instrument applying the jurisprudential inquiry learning strategy provides wide opportunities for the students to state their opinions during the class. It opens the possibility of interactions between students and the peers and the teacher. Therefore, it is concluded the learning instruments for teaching and learning fiqh using the jurisprudential inquiry learning strategy at Madrasah Tsanawiyah are utilizable.

Table 1. The Evaluation of Instrument Rationale Aspects

\begin{tabular}{rrrr}
\hline Aspect & Score & Mean & Conclusion \\
\hline
\end{tabular}




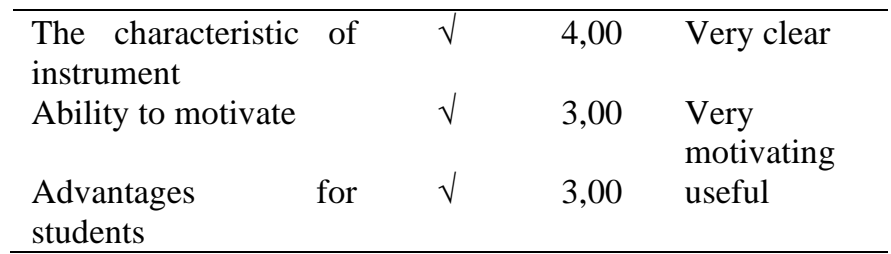

The evaluations shown in table 4:7 describe the rationale of the learning instrument which is very clear, motivating, and useful. Therefore, the evaluators conclude that the learning indicators arranged have met the students' competence for Madrasah Tsanawiyah level. Related to the way materials are presented using the learning instruments jurisprudential inquiry-based strategy for learning fiqh, evaluators sum up that the presentation is attractive that it easily catches students' attention, and it helps them to focus and concentrate more during the lesson.

Students' engagement during the learning process meets the expectation of the program since there are a lot of students participate and give responses during the class. The steps are clear and the presentation is systematic. The activities are students' interest-oriented. The learning instrument using the jurisprudential inquiry learning strategy is believed to be helpful and flexible. It gives opportunities for students and teachers to interact in the class when they learn fiqh.

\section{Development Practicality}

The practicality aspect in the research relates to how practical the learning instrument used in teaching and learning fiqh applying the concepts of jurisprudential inquiry learning. The evaluation for the practical aspect is obtained from teachers who apply the model. The evaluation is described in the following table:

Table 2. Practicality Aspect

\begin{tabular}{clccc}
\hline No & \multicolumn{1}{c}{ Aspect Evaluated } & Score & $\begin{array}{c}\text { Evaluation } \\
\text { Percen }\end{array}$ & Criteria \\
\hline 1 & $\begin{array}{l}\text { The steps of learning are } \\
\text { suitable to the concepts of } \\
\text { jurisprudential inquiry learning } \\
\text { strategy } \\
\text { The steps of learning are } \\
\text { explained systematically } \\
\text { Teachers can follow the steps of } \\
\text { learning } \\
\text { Students thinking ability } \\
\text { improves as well as their ability } \\
\text { to make decisions } \\
\text { Total }\end{array}$ & 8 & 80 & practical \\
& 8 & 8 & 80 & practical \\
\end{tabular}

Based on the table above, it is known that the implementation of learning fiqh applying the model of jurisprudential inquiry learning strategy scores 82.5 and within the practical category. The data show that the learning instrument developed is practical to be used.

\section{The Effectiveness}

To see how effective the use of learning instrument applying the jurisprudential inquiry learning strategy, therefore, the experiment is done to two different groups of class; the control group and experimental group.

\section{The Implementation of Learning Fiqh Applying the Jurisprudential Inquiry Learning Strategy}

Learning fiqh using the jurisprudential inquiry learning strategy is done within several steps: a) identifying the issue, teachers direct the students to choose a topic or issue to be discussed, the teachers assist students to 
be aware of facts in the issue. b) positioning, students are asked to decide their positions toward the issue, c) elaborating the arguments to support what has been decided.

Students' positions or behavior or opinions are elaborated by showing them some opposites ideas. It is seen whether or not they can stay on what they believe by asking them to elaborate more logical arguments to strengthen their positions. d)clarifying, it is to see whether the students stick on what they say or they have the intention to change, it depends on their arguments of phase four. If their arguments are strong, they can be consistent, if they are not, they possibly change. e) testing the assumption about facts, definitions, and consequences used by the students. The teacher assists the students to see whether the arguments they make are valid, or relevant.

In the learning process, the implementation of the strategy can help students to participate actively and be more creative, have the courage to state social facts, opinions, to respect other ideas, have ethics, be able to lead class discussion, to work together, be responsible, to find and process information, to analyze and conclude, and to be critical and democratic in responding problems faced in the class during the lesson. Furthermore, the findings show that the jurisprudential inquiry learning strategy helps students to enhance their independent learning ability (individually or within a group), to deliver their knowledge in a discussion. The strategy also improves students' appreciation and learning experiences that they have courage to state what they think and believe to be true, to respect their friend ideas, to do role play, to lead discussions, to work together, to be responsible, to find and process information, to analyze and make a conclusion, and to manage their critical thinking ability, and be democratic when they learn fiqh applying the jurisprudential inquiry learning strategy.

To measure the effectiveness of the development of the learning instrument using the jurisprudential inquiry learning strategy, an experiment is done within two classes; the experimental group and the control group.

\section{Students' Pre-test}

The students' pre-test in the experimental class consisting of 42 students, and the control group that also consists of 42 students can be seen on the following table:

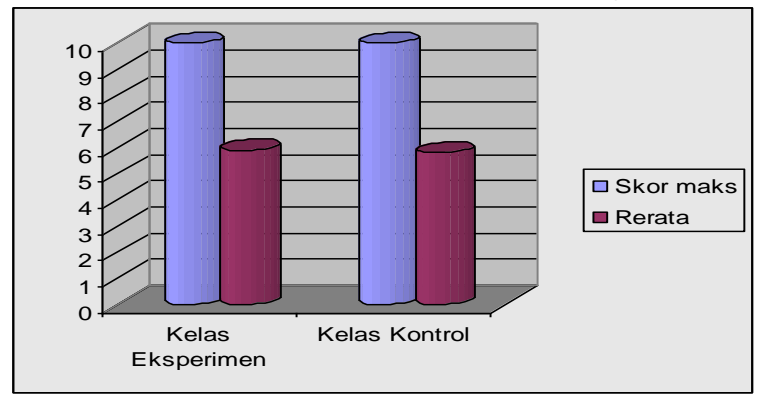

The table above shows the mean score of pretests done to the experimental group is 5.90 while the control group's mean score is 5.81 out of 10 . To test whether there are differences between the two mean scores, normality and homogeneity test are done.

The tests are done to fulfill the requirements of the mean scores test by using the t-test or the parametric statistic test. The normality criteria for data distribution are determined by testing the suitability between the data of observation using a normal distribution model. The suitable criterion is calculated using the distribution of ChiQuadrat $\left(\chi^{2}\right)$. The criteria are determined by comparing $\chi^{2}$ obtained from the calculation of $\chi^{2}$ from $\chi^{2}$ distribution table using $\alpha=0,05$. The calculation of $\chi^{2}$ and $\chi_{(1-\alpha)(\mathrm{dk})}^{2}$ or $\chi_{\text {tabel }}^{2}$ for experimental group and control group can be seen on the table. $\chi_{\text {hitung }}^{2} \chi_{\text {tabel }}^{2}$ Therefore, the data distribution of the two groups is normal. After the normality test is done, the data are tested for their homogeneity. It is done by examining the similarity between the variant of the experimental group and the control group.

The $F$ is used as the criteria for homogeneity of the two groups' variants. The homogeneity criteria are obtained by comparing the higher variant to the lower one, defined as $F$. The $F$ then is compared with the $F$ of distribution where $\alpha=0,05$. Based on the 
similarity of the variants, it is obtained that $F$ is lower than the $F_{\text {tabel }}$. It means the distribution of the pre-test score of both data is homogenous.

From the data analysis of the two pretests, it is obtained that both groups are normal and homogenous. Therefore, the test for mean score differences can be done through a statistic parametric test. The significant criteria are seen by calculating the $t$. the $t_{c a l}$ is then compared with the $t$ from the table distribution, where the $\mathrm{dk}=\mathrm{n}_{1}+\mathrm{n}_{2}-2$ and the probability is $(1-1 / 2 \alpha)$.

From the calculation, it is obtained that $t_{\text {cal }}$ is 0.801 while $t_{\text {tabel }}=2,36$ where $\alpha=$ 0,05 dan $\mathrm{dk}=82$. It means $t_{\text {cal }},<t_{\text {tabel, }}$, means for its hypothesis test, the hypothesis is 0 , means, the hypothesis is accepted. Therefore, based on the statistic test, it can be concluded that students in both classes are on the same level of competency. It is then possible to say that the research is conducted in two different classes where the students' competencies are equal.

\section{Students' Post-test}

After the treatment that is learning fiqh by applying the concepts of jurisprudential inquiry learning strategy, students' learning outcome is then evaluated again. The students' post-test result of the experimental group is compared to the posttest result of the control group. The student's grade is described based on the following picture:

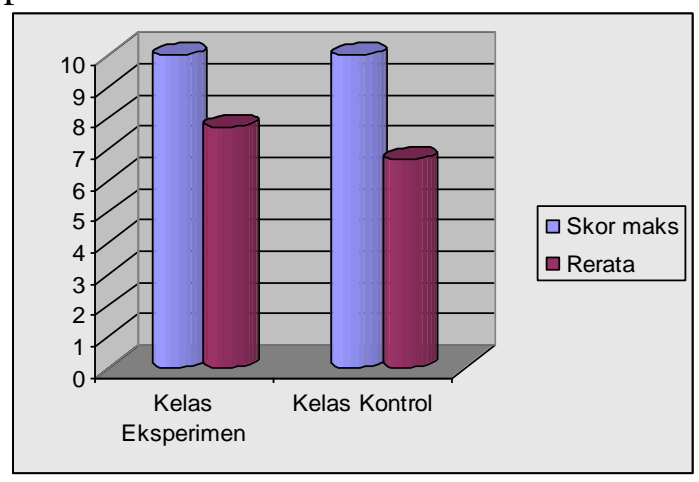

The normality test is determined by using the suitability test $\chi^{2}$ (chi-quadrat). From the data analysis, it is found that the score of $\chi^{2}$ (chi-quadrat) for both groups shows that the data distribution is not normal, $\chi_{\text {hitung }}^{2}$ for both groups compared with the $\chi_{\text {tabel }}^{2}$ from distribution table $\chi^{2}$. Therefore, the data again are tested using parametric statistics.

The data are tested for their homogeneity. The test is done by testing the similarity of both variants. The higher variant is defined as $F$ where $F$ is the homogenous criterion. Based on the calculation of the $F$ score from the post-test of both groups, it is found that the $F$ is 0.06 which lower than the $F_{\text {tabel }}$ where $\alpha=0,05$. Therefore, it is possible to say that the data distribution of the post-test from the two groups are homogenous.

Referring to the normality and homogeneity test of data distribution obtained from the post-test of the experimental group and control group, it is concluded that the distribution is normal and homogenous. The hypothesis is then tested by using the parametric statistic test. The hypothesis is tested by testing the means score using the $\mathrm{t}$ test. Based on the data analysis, it is obtained that the $t_{\text {tabel }}$ is 0.81 where $\alpha=0,05 \mathrm{dk}=82$ (from $42+42-2$ ). According to the calculation, it is obtained that $t_{\text {cal }}>t_{\text {tabel }}$ which means that the hypothesis test is $\left(\mathrm{H}_{0}\right)$ where it is rejected. Therefore, based on the test of the mean scores, it is gained that there is a difference between the data obtained from the experimental group and the control group because such treatment is given.

\section{Students’ N-Gain Score}

After obtaining the students' learning outcomes as a result of the implementation of jurisprudential inquiry learning strategy, the students are evaluated again; both from the experimental group and control group. The normality test is determined using the suitability of $\chi^{2}$ (chi-quadrat). Then the data population is tested for its homogeneity. The homogeneity test is done by testing two variants. The comparison between high variant and lower variant is defined by $F$, where it is used as the homogeneity criterion. 
Referring to the homogeneity analysis test, the $F$ obtained is 0.06 , lower than $F_{\text {tabel }}$ where $\alpha=0,05$. Thus, the N-Gain from the distribution of data scores from both groups is homogenous. Based on the normality test and homogeneity test, the distribution of the data score of the experimental and control group are normal and homogenous. Therefore, the hypothesis is done using a parametric statistic test. The hypothesis is tested using two mean scores using the t-test formula. The data show that the $t_{\text {cal }}$ is 0.87 dan nilai $t_{\text {tabel }}$ is 3.36 where $\alpha=0,05$ and $\mathrm{dk}=82$ (dari $42+42-2$ ).

Based on the calculation obtaining $t_{c a l}$ $>t_{\text {tabel }}$ indicates that the hypothesis is $\left(\mathrm{H}_{0}\right)$ and $\mathrm{H}_{0}$ is rejected. Thus, it is possible to say that there are differences between the scores of the control group and the scores of the experimental group because such treatment is given to one of the groups. Because the $\mathrm{N}$ Gain of the control group is higher than the experimental group, students that are taught using the jurisprudential inquiry learning strategy obtain more improvement. Based on the means score of the Gain, the experimental group obtained 0.032 , which is within the 'medium' category, while the control group obtains 0.034 which is in the 'low' category. It indicates that the students who are taught using the jurisprudential inquiry learning strategy in learning fiqh get more improvement compared to the students who are taught figh using conventional strategy.

\section{RESULT AND DISCUSSION}

One important thing that students need to get from learning figh is the need to study more which stimulates and motivates them to study harder and seriously therefore they can achieve the goals of education. The research findings show that the jurisprudential inquiry learning strategy improves students learning outcomes in studying fiqh significantly. The trend changes from the 'medium' category into the 'high' category.

It is seen from the mean scores of the pre-test which is 5.90 and within the 'low' category, but then becomes 7.64 which is the 'high' category. Meanwhile, the control group obtains 5.18 on pre-test and then becomes
6.67 on post-test, where both scores belong to the 'low' category. Students who are taught by implementing the jurisprudential inquiry learning strategy improve their scores more than students who are taught using a conventional way.

Therefore, the students that join the class applying the jurisprudential inquiry learning strategy, seen from their learning outcomes, obtain significant improvement compared to the conventional class. The research data also show that the research is in the valid category because it already reflects the state of knowledge (Plomp.T \& Nieveen, 2007). It is also effective because it helps students to obtain the set instructional objectives (Firman, 2000). It is also believed practical and easy to be used because it is implemented based on the empirical measurement data (Surapranata, 2006).

Referring to the previous research data and analysis, the teachers must implement the jurisprudential inquiry learning strategy to teach fiqh because it triggers students' critical thinking ability, students' courage, and motivation. The strategy creates an atmosphere where students want to study more and are actively involved in all learning activities. The jurisprudential inquiry learning strategy triggers students' external motivation which is one of the successful indicators of the strategy.

\section{CONCLUSION AND RECOMMENDATION}

Developing the learning model for teaching and learning fiqh using the jurisprudential inquiry learning strategy has scientifically proven its success to improve students learning outcomes at the MTs Koto Tuo. The implementation of the learning model using the jurisprudential inquiry learning strategy stimulates students' behavioral changes in studying. The students are more aware of their responsibility as students, they care and they work better, they are disciplined in following each learning activity provided by the teachers during the lesson. 
Many students do their activities and learn fiqh by referring to the strategy of jurisprudential inquiry learning. They apply the strategy not only in the class but also outside the class. The learning fiqh applying jurisprudential inquiry learning strategy equipped with the learning steps have been valid. The teachers confirm that the learning process that applies the jurisprudential inquiry learning strategy helps students to be more creative during the lesson. It is possible to say that the strategy is practical. Moreover, there are significant differences between the students' learning outcome obtained from the experimental group, the group that is given such treatment, and the learning outcomes obtained from the control group, that is not given treatment. The experimental group outcomes are better than the control group learning outcome.

\section{REFERENCES}

Akbar, A. (2021). Pentingnya Kompetensi Pedagogik Guru. JPG: Jurnal Pendidikan Guru, 2(1), 23-30 http://dx.doi.org/10.32832/jpg.v2i1.40 99.

Amalia, R., \& Supranata, I. K. G. (2020). Peran Hubungan Masyarakat Kementerian Pendidikan Dan Kebudayaan Republik Indonesia Dalam Diseminasi Informasi Melalui Media Sosial Facebook. PANTAREI, 4(2).

Arifin, M. B. U. B., Nurdyansyah, I. R., \& Fauji, I. (2019). Teaching media of fiqh magazine model to improve prayer understanding in primary school students. Universal Journal of Educational Research, 7(8), 18201825.

Budiman, A., Alamin, N. S., Ashari, R., \& Fahirah, P. H. (2021). Application Interactive Learning Media in Macromedia Flash 8 to Improve Learning Outcomes of Fiqh Lesson. 1 st International Conference of Education, Social And Humanities (INCESH 2021), 1-3.
Budiman, A., \& Samani, M. (2021). The Development of Direct-Contextual Learning: A New Model on Higher Education. International Journal of Higher Education, 10(2), 15-26 doi:10.5430/ijhe.v10n2p15.

Busyro, B. (2018). Utilizing the Assets Acquired from Illegal Conducts A Study of Fiqh Maqâshid of Yûsuf alQaradlâwî. Al-Ihkam: Jurnal Hukum Dan Pranata Sosial, 13(2), 231-253.

Firman, H. (2000). Penilaian Hasil Belajar dalam Pengajaran. Bandung: FMIPA UPI. FMIPA UPI.

Hasanah, S. U. (2019). Studi Komparasi Penerapan Metode Active Learning Model Reading Aloud Dan Metode Konvensional Model Ceramah Dalam Pembelajaran Bahasa Arab Dan Pengaruhnya Terhadap Respon Siswa Kelas V Mi Ma'arif 01 Pahonjean Majenang. Jurnal Tawadhu, 3(1), 804-822.

Hasbullah, H., Juhji, J., \& Maksum, A. (2019). Strategi belajar mengajar dalam upaya peningkatan hasil belajar pendidikan agama Islam. EDURELIGIA: Jurnal Pendidikan Agama Islam, 3(1), 17-24 DOI: https://doi.org/10.33650/edurelig ia.v3i1.859.

Horsley, T. L. (2010). Innovative learning activity. Journal of Nursing Education, $\quad 49(6), \quad 363$ DOI:10.3928/01484834-20090521-02.

Ismail. (2008). Strategi Pembelajaran Agama Islam Berbasis Paikem. Rasail Media Grup.

Ismail, I. (2016). Eksistensi Rakyu Dalam Pengembangan Hukum Islam. $A l$ Hurriyah: Jurnal Hukum Islam, 01(01), 2549-4198 DOI :10.30983/alhurriyah.v1i1.480.

Mansir, F., Tumin, T., \& Purnomo, H. (2020). The Use of Active Learning Methods In Learning Fiqh Subjectat Islamic 
Boarding School. Lentera Pendidikan: Jurnal Ilmu Tarbiyah Dan Keguruan, 23(1), 173-182 https://doi.org/10.24252/lp.2020v23n1 i14.

Nasution, M. K. (2018). Penggunaan metode pembelajaran dalam peningkatan hasil belajar siswa. Studia Didaktika, 11(01), 9-16.

Nava-Aguirre, K. M., Garcia-Portillo, B. I., \& Lopez-Morales, J. S. (2019). Collaborative online international learning (COIL): An innovative strategy for experiential learning and internationalization at home. In The Palgrave Handbook of Learning and Teaching International Business and Management (pp. 721-746). Springer DOI: $\quad$ 10.1007/978-3-030-204150_34

Neil, G. J., \& Higham, P. A. (2012). Implicit learning of conjunctive rule sets: An alternative to artificial grammars. Consciousness and Cognition, 21(3), 1393-1400

https://doi.org/10.1016/j.concog.2012. $\underline{07.005}$.

Nisak, N. M., Arifin, M. B. U. B., Fahyuni, E. F., \& Rahmawati, I. M. (2021). The Development of Comic Formatted Fiqh Textbook For Islamic Elementary School. European Journal of Education Studies, 8(1) http://dx.doi.org/10.46827/ejes.v8i1.3 513 .

Oxford, R. L., Rubin, J., Chamot, A. U., Schramm, K., Lavine, R., Gunning, P., \& Nel, C. (2014). The learning strategy prism: Perspectives of learning strategy experts. System, 43, 30-49

https://doi.org/10.1016/j.system.2014. 02.004.

Plomp.T, \& Nieveen, N. (Eds.). (2007). An Introduction to Educational Design Research. Netherlands Institute for Curriculum Development (SLO).
Priambodo, A., Widyaningrum, N., \& Rahmat, H. K. (2020). Strategi Komando Resor Militer 043/Garuda Hitam dalam Penanggulangan Bencana Alam di Provinsi Lampung. PERSPEKTIF, 9(2), 307-313 https://doi.org/10.31289/perspektif.v9i 2.3588 .

Priansa, D. J. (2017). Pengembangan strategi dan model pembelajaran: Inovatif, kreatif, dan prestatif dalam memahami peserta didik.

Radianti, J., Majchrzak, T. A., Fromm, J., \& Wohlgenannt, I. (2020). A systematic review of immersive virtual reality applications for higher education: Design elements, lessons learned, and research agenda. Computers \& Education, $\quad 147, \quad 103778$ https://doi.org/10.1016/j.compedu.201 9.103778.

Rahman, R., Kher, D. F., Rani, Y. A., Murniyeti, \& Rezi, M. (2019). Efforts in Improving The Quality of Education Through Educator's Profesionalism. BICED 2019: Proceedings of the 1st EAI Bukittinggi International Conference on Education.

Rezi, M., Sasmiarti, S., \& Helfi, H. (2018). Merokok Dalam Tinjauan Hukum Islam (Studi Nash-Nash Antara Haram Dan Makruh). Al Hurriyah: Jurnal Hukum Islam, 3(1), 53-66 DOI : 10.30983/alhurriyah.v3i1.534.

Rido, A., Ibrahim, N., \& Nambiar, R. M. (2015). Interaction strategies of master teachers in Indonesian vocational classroom: A case study. $3 L$ : Language, Linguistics, Literature ${ }^{\circledR}$, 21(3) .

Saifulloh, A. M., \& Darwis, M. (2020). Manajemen Pembelajaran dalam Meningkatkan Efektivitas Proses Belajar Mengajar di Masa Pandemi Covid-19. Bidayatuna: Jurnal Pendidikan Guru Mandrasah Ibtidaiyah, 3(2), 285-312 
https://doi.org/10.36835/bidayatuna.v $3 \mathrm{i} 2.638$.

Sanjaya, W. (2010). Strategi Pembelajaran Berorientasi Standar Proses Pendidikan. Prenada Media Group.

Schumacher, D. J., Englander, R., \& Carraccio, C. (2013). Developing the master learner: Applying learning theory to the learner, the teacher, and the learning environment. Academic Medicine, 88(11), 1635-1645.

Seels, B. B., \& Richey, R. C. (2012). Instructional technology: The definition and domains of the field. IAP.

Setyosari, P. (2010). Metode penelitian pendidikan dan pengembangan. Kencana.

Sigit, D. V., Azrai, E. P., Heryanti, E., Ichsan, I. Z., Jajomi, Y. P., \& Fadrikal, R. (2019). Development green consumerism e-book for undergraduate students (gc-ebus) as learning media in environmental learning. Indian Journal of Public Health Research and Development, 10(8), 2026-2031.

Sugiyono, M. (2015). Penelitian \& pengembangan (Research and Development/R\&D). Bandung: Penerbit Alfabeta.

Supriyanto, D. (2018). Variasi Model Pembelajaran Guru MI pada di MI Miftahul Ulum Rowogempol Lekok
Pasuruan. MODELING: Jurnal Program Studi PGMI, 5(2), 247-254.

Surapranata, S. (2006). Analisis, Validitas, Realibilitas, dan Interpretasi Hasil Test Implementasi Kurikulum. Remaja Rosdakarya.

Tamrin, M., Azkiya, H., \& Sari, S. G. (2017). Problems faced by the teacher in maximizing the use of learning media in Padang. Al-Ta Lim Journal, 24(1), 60-66 Doi:10.15548/jt.v24i1.262.

Taufik, T. (2012). Mozaik Pembelajaran Inovatif. Suka Bina Press.

Thohari, A. (2013). Epistemologi Fikih Lingkungan: Revitalisasi Konsep Masalahah. Az Zarqa': Jurnal Hukum Bisnis Islam, 5(2).

Wijanarko, Y. (2017). Model pembelajaran Make a Match untuk pembelajaran IPA yang menyenangkan. Taman Cendekia: Jurnal Pendidikan Ke-SDAn, 1(1), 52-59 https://doi.org/10.30738/tc.v1i1.1579.

Wyatt-Smith, C., \& Klenowski, V. (2014). Elements of better assessment for the improvement of learning. In Designing assessment for quality learning (pp. 195-210). Springer DOI: $\quad 10.1007 / 978-94-007-5902-$ 2_13 